\title{
Institutional Characteristics Influencing Bachelor of Science Nursing Student Performance in the Nursing Council of Kenya Licensure Examinations in Kenya
}

\author{
Anne Asiko Okanga ${ }^{1}$ \\ John Okoth Ogur ${ }^{2}$ \\ John Arudo
}

'MScN, School of nursing and midwifery, Masinde Muliro University of Science and technology, Kenya

${ }^{2}$ School of nursing and midwifery, Masinde Muliro University of Science and technology, Kenya

${ }^{3}$ Department of Clinical Nursing and Health Informatics, School of nursing and midwifery, Masinde Muliro

University of Science and technology, Kenya

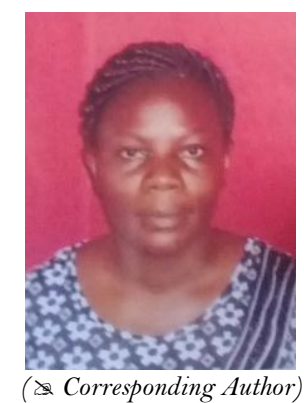

\begin{abstract}
Kenya has seen a paradigm shift in nursing education sector recording high rates of enrolment of students to training while their performance in Nursing Council of Kenya (NCK) examination remained variable and unpredictable. This study evaluated performance of BSc nursing students in NCK examinations by examining institutional characteristics in relation to performance. NCK identified it as priority area of research. The study used qualitative and quantitative approach to collect data retrospectively. The records of 1292 students who sat examinations in the period between the period July 2012 - June 2015 from NCK nurses database was used. Cluster and purposive sampling were done for key informants interviewed from nursing schools. Quantitative data was converted from MS Access to SAS and analyzed. Odds ratio was used to measure strength of association between institutional characteristics and performance with $p \leq 0.05$ being considered significant. Qualitative data was recorded and transcribed for content analysis. The proportion of those who passed and aged 30 years and above (upgraders) was significantly higher than those who were less than 30 years (OR: 1.6, 95\% CI: 1.2-2.2, p=0.002). Both Class attendance policy and faculty experience had marginal positive association (OR: 0.4, 95\%CI: $1.0-$ 2.0, $\mathrm{p}=0.068)$ and (OR: 0.7, 95\%CI: 0.5-1.0, $\mathrm{p}=0.068)$ respectively. Admission criteria was reported by key informants to be influencing performance, In conclusion the study identified faculty years of experience and class attendance policy were associated with performance. Mode of study was reported to influence performance by key informants. The study recommended training institutions to continue with upgrading Programmes, uphold class attendance policy, select faculty based on experience. Results can be used to predict performance and facilitate development of policies for recruitment and examination.
\end{abstract}

Keywords: Performance, NCK examination, Institutional characteristics.

Citation | Anne Asiko Okanga; John Okoth Ogur; John Arudo (2017). Institutional Characteristics Influencing Bachelor of Science Nursing Student Performance in the Nursing Council of Kenya Licensure Examinations in Kenya. Journal of Education and eLearning Research, 4(1): 28-36.

History:

Received: 4 April 2017

Revised: 4 May 2017

Accepted: 9 May 2017

Published: 15 May 2017

Licensed: This work is licensed under a Creative Commons

Attribution 3.0 License (cc)

Publisher:Asian Online Journal Publishing Group
Contribution/Acknowledgement: All authors contributed to the conception and design of the study.

Funding: This study received no specific financial support.

Competing Interests: The authors declare that they have no conflict of interests.

Transparency: The authors confirm that the manuscript is an honest, accurate, and transparent account of the study was reported; that no vital features of the study have been omitted; and that any discrepancies from the features of the study have been omitted;
study as planned have been explained.

study as planned have been explained.
Ethical: This study follows all ethical practices during writing.

\section{Contents}

1. Introduction

2. Methodology

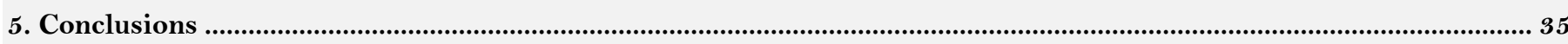

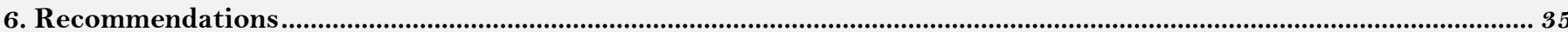

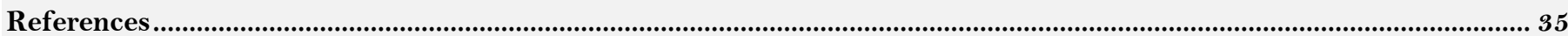




\section{Introduction}

Nurses and other members of health professions handle human lives necessitating no room for mistakes because any error done could cost the life of a patient. This calls on them to be sensitive, caring, committed, and equipped with skills and knowledge in performance of their roles (Oh et al., 2011). Current advances in medical technology and demands of health services requires quality training for the student nurses (Idowu, 2013). It demands that they should possess recognized qualification before they can be registered and practice legally in any country (Oh et al., 2011) and this qualification comes with a pass in their licensure examination. This demands make academic performance a priority to students as well as the teachers (Ukpong and George, 2013). In the USA, nursing education and practice is controlled from within the profession through the state board of nursing with the major goal of every programme being to graduate students that are able to pass NCLEX-RN on their first attempt (Coons, 2014). The board exam establishes the newly graduate nurse's readiness to render safe and competent service to health consumers through the pass rate of the NCLEX-RN licensure exam (Cooper, 2012). In Pennsylvania, the state board of nursing requires every school to maintain a minimum percentage pass of graduates to stay open (Carrick, 2011).

In China, High pass rates on the examination enhance nursing schools reputation, retain accreditation, and appeal to new students. This makes passing the NQEX-RPN a critical issue for nursing student and nursing school (Xiao et al., 2014). In Nigeria educators, examiners and regulatory agencies severally complain of poor performance of the students in the licensure examination (Ogbonnaya et al., 2014). Educational institutions determine the criteria for admission for their students basing on researched evidence thus providing great potential for academic success (Burns, 2011). Such data is highly utilized by nurse educators (Manieri et al., 2015). In Kenya as a requirement for admission to a nursing school, the BScN graduates must have a specified mean grade for university admission and cluster subject grades required for the nursing program (Nyangena et al., 2013). A study by Aleyamma found out that students had presented several reasons for not performing well in academics to include lack of parental guidance, inadequate travel, language barrier and admission of student $\mathrm{s}$ with lower qualifications in the Nursing program (Alleyama et al., 2012).

The nature of nursing profession requires that students who would like to be nurses be properly screened to determine their aptitudes and qualifications. A study by Ogbonaya identified a strong relationship between entry qualifications and performance in the licensure examination which was statistically significant $(\mathrm{r}=0.48 ; \mathrm{P}<0.05)$ (Ogbonnaya et al., 2014). Kija et al. (2016) demonstrated that there was a significant positive relationship between student entry qualifications and academic performance in the nursing schools $<\mathrm{P}=0.022$ and (Pitt et al., 2012) also identified a strong relationship $(\mathrm{P}=0.001)$ between secondary school performance and the performance in the licensing examination. On the contrary, Oducado and Penuela (2014) found the high school grade to be nonsignificant in relation to performance $(\mathrm{t}=0.441)$.

Part time and distant leaners have demonstrated higher learning outcomes and abilities in patient care and managerial roles (Sharchar, 2010). The performance of students in private schools of nursing in the Nursing and Midwifery Final Qualifying Examination was found to be better than the performance of student nurses in the Mission school of nursing in the same examination which was better than that of State nursing schools (Idowu, 2013). A study by Kija et al. (2016) revealed there was no difference basing on type of school $\mathrm{P}=0.059$. There was a significant difference in the facilities available in public schools as compared to private schools and this could influence performance regardless of the school type (Sabitu et al., 2012).

There has been changing roles of teachers from them being teacher centered to being student centered (Hamid et al., 2012). Teacher qualities among them experience and qualifications predicted the performance of the teacher which further impacted on the performance of the students (Hamid et al., 2012). The most influential force affecting student performance is the teacher thus needing the teacher to undergo quality education (Bishop and Verleger, 2013). Higher teacher qualifications is highly attributed to good student performance (Idowu, 2013). Teacher education showed positive outcomes in student performance (Saddler et al., 2012). In education teacher experience is the key factor in personnel policies that affect current employees with less experienced teachers tending to be more effective than those that have stayed long in the particular employment (King, 2010). Darling (2010) in his study identified that with continued teacher performance assessments longer serving teachers performed better because of the increased chances they had on improving on their previous performances and this would automatically reflect in improved leaner outcomes

The goal of educational activities is to pass all students that demonstrate sufficient knowledge of the syllabus content and fail those who do not (Idowu, 2013). Student attendance is a major concern for educators and poor attendance hinders academic achievement (Amitava et al., 2010). Both teacher and student absenteeism results in reduction in academic performance (Jafta, 2013). Among the teacher related factors that were found to have a high impact in relation to performance was lateness and absenteeism (Alos et al., 2015)

By using innovative methods, faculty are better able to model students and the students are better able to integrate theory and clinical practice (Missildine et al., 2013). Method of delivery was identified as one of the factors that positively or negatively influenced the performance of students in their examination with innovative methods exhibiting high impact than the traditional methods (Alos et al., 2015). Freeman et al. (2013) in a meta-analysis of several studies identified that several studies had recorded poor performance of students taught using traditional lecture methods as compared to taught using innovative methods.

In Kenya, NCK in CAP 257 of the laws of the country prescribes and conduct examinations for persons seeking registration or enrolment under the Act (Nyangena et al., 2013). A pass in examination depends on many factors that can include institutional factors and so the evaluation of teaching and learning process is done on the basis of set standards (Idowu, 2013). The Kenya registration examination performance 2012 shows $79.5 \%$ pass rate among $\mathrm{BScN}$ students with 20.5\% failing (Kenya Nursing Workforce Report, 2012). Overall BScN performance of 2015 January indicates O \% distinctions, (3) 0.54\% credits, (491) $88.63 \%$ passes, (52) $9.39 \%$ fails with (8) $1.44 \%$ withdrawals (NCK, 2015).

Kenya has seen a paradigm shift in the nursing education sector recording high proportions of enrolment of nursing students to various levels of training while the performance of the students in the NCK examination 
remained variable and unpredictable (Nyangena et al., 2013). Several factors play a role in the performance of nursing students in their national licensure examination. Concerns about the shortage of nurses and public expectations regarding the value of services consumed have created need for monitoring performance (Dubois et al., 2013). Many studies had been done to evaluate some of the factors that influence performance in any examination and this study evaluated institutional characteristics.

\subsection{Objective of the Study}

This study was conducted to examine institutional characteristics' and their relationship with performance in the NCK examinations by the BScN students in Kenya.

\section{Methodology}

A retrospective, qualitative and quantitative study was adopted. The researcher used record review in gathering information from NCK database. An analysis of three year performance from 2012 July to 2015 June was done. The researcher utilized key informant interviews to get data from institutional heads of sampled schools of nursing. The study population comprised all BScN students' records of NCK examination in the NCK database from 2012 July to 2015 June totaling to 1292 and heads of schools of nursing respectively.

The researcher started with cluster sampling where the units were categorized into three clusters; private, public and faith based followed by simple random sampling of schools. Proportionate allocation of participants into the cluster was done basing on their level of representation. For key informants, purposive sampling was done where all heads of schools of nursing were interviewed and the chairperson of the department dealing with examination at the NCK. All eligible candidates' records were included in the sample for data base analysis. Number of institutions meeting the inclusion criteria; Public-5, Private- 1, faith based -2. Sampled institutions therefore included three public (University of Nairobi, Masinde Muliro University of Science and Technology and Moi University), one private (Great Lakes University) and two faith based (University of Eastern Africa Baraton, Kenya Methodist University) institutions.

Research tool was adopted from one used by the Task Force report from the nursing education institutions and faculty (RENRE, 2014). It was then refined and a pretest of the tool was carried out in a similar institution and the tool further refined. Key informant interviews were conducted by the researcher.

\subsection{Inclusion and Exclusion Criteria}

Only institutions offering $\mathrm{BScN}$ education and had enrolled their students for nursing council examinations during the reference period were included in the study. Also all institutions included were those presenting their students for nursing council examinations at least twice a year. Students on upgrading face to face and direct entry were included while distant and e learning were excluded. Only heads of institutions were included in the sample. All student data for 2012 July to 2015 June were in the sample and the rest excluded.

\subsection{Data Management}

Raw data was double checked for accuracy and coded. Data entry was done using a customized Excel and the SAS software. By looking at the data from the nursing council of Kenya, the demographic data was identified using a unique index key identifier that yielded 8,678 candidates. From this the index id was merged with the grade yielding 2356 candidates and a perfect merge yielded 2,354 candidates after eliminating the repeated numbers. After excluding the universities that were not meeting the eligibility criteria candidates remained 1399. Since we were interested in the first pass any results any paper that had a zero indicated the examination was a repeat and therefore were excluded. This left us with 1292 records of students in the data base for use. Any duration of four years to six years was regarded as direct entry while the rest were upgraders to help us identify the mode of study. However the period lapse between completion of training and date of examination could not be elicited from the data base information provided.

\subsection{Data Analysis}

Data analysis was done using a customized Excel and the SAS software. To provide a profile of students, frequencies, means, range and standard deviations for data was done Bivariate analysis of dependent and independent variables was also done with $\mathrm{p}$ [less than or equal to 0.05], being considered significant. To determine relationship between selected variables and performance in NCK examination regression analysis was used because the dependent variable was dichotomous. Regression analysis was computed to test relationship on institutional characteristics. Dependent variable tested reflected either passing or failing of the nursing council examination while the independent variables tested reflected institutional characteristics. Content analysis was done for qualitative data.

\subsection{Ethical Considerations}

The researcher sought approval to conduct the study from Masinde Muliro university school of graduate studies, and ethical clearance from the Research Ethics Committee of Masinde Muliro University and permit from NACOSTI. The researcher also sought permission from the nursing council of Kenya to utilize their data. Random selection of schools was done for fairness. For justice, participants' information was removed prior to the compiling and analysis and the database was maintained secure throughout the study to ensure that no harm to individuals or institutions occurred. Informed consent was sort from participants in the key informant interviews from the institutions involved and participants were allowed to withdraw from study at any point without suffering any consequences. 


\section{Results}

\subsection{General Findings}

The total number of students who sat the NCK examination for the period July 2012 to June 2015 was 1292 while for the two complete years 2013-2014 was 790. The highest number of students who sat for examination was recorded in the year 2014 which was $470(36.4 \%)$ students. There was a higher number of students sitting examinations in 2014 compared with the previous year 2013 which was 320 (24.7\%). For 2012 which had 97 (7.6\%) students and 2015 that had $405(31.3 \%)$ data was only captured for half a year.

Figure 1. Illustrates that, during the 2012 period UEAB recorded the highest proportion of students being 39 $(40.2 \%)$ for that year then experienced a drop in 2013 but proportion went up again in 2014. GLUK on the other hand started on slightly higher note although lower than KEMU and UEAB, but then experienced a drop throughout the rest of the period. KU had a drop in the year 2013 but went up again in 2014. MMUST experience an increase throughout the period while MOI and UON increased their proportion of enrolment in 2013 and dropped in 2014 .

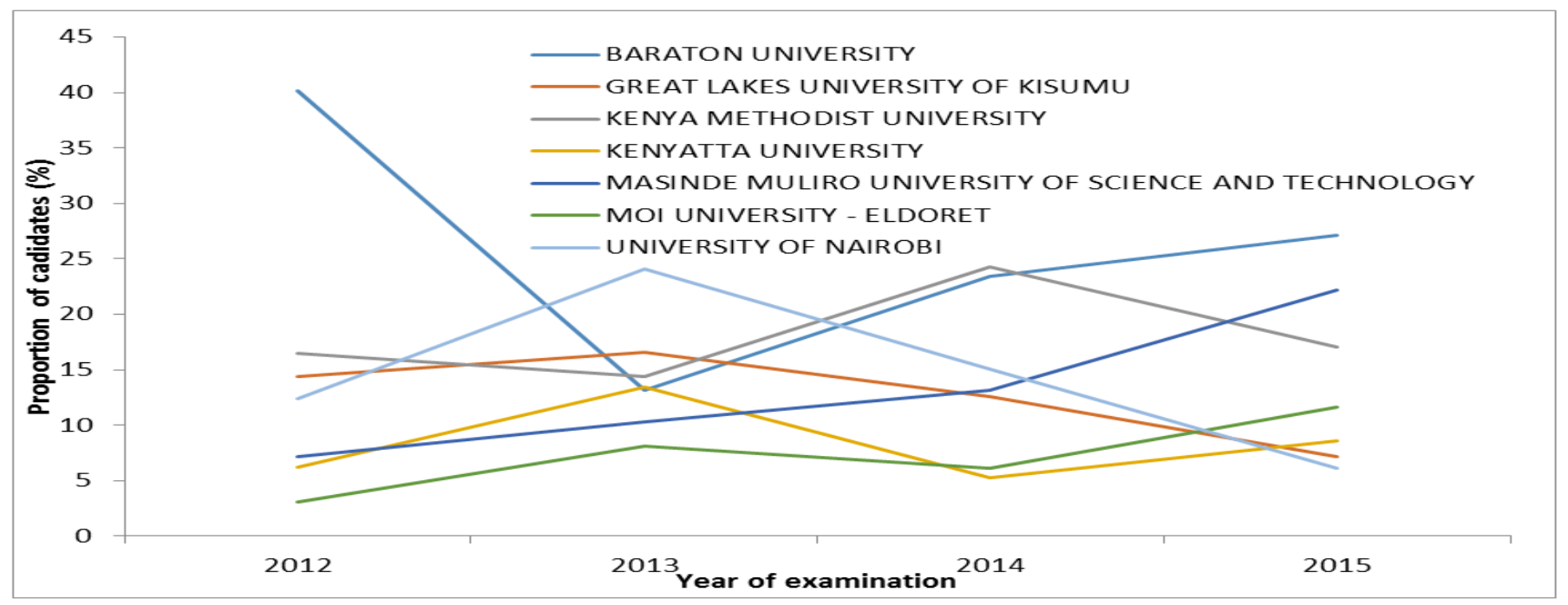

Source: From this study

Figure-1. Graph showing Year of Examination by institution

\subsection{Demographic Characteristics of Students}

Results on age group comparison shows that Majority of the students were between ages of 20-29 years old and that was $667(51.6 \%)$ followed by ages of 30 to 39 years being $390(30.2 \%)$ while the least were those above 50 years $55(4.3 \%)$ of the total students that sat for the nursing council examinations during the reference period. UON had the highest population of students 173 out of 185 (93.5\%) being ages $20-29$ years while the least was GLUK having only 17 out of $155(11 \%)$ of the students being age $20-29$ years old. KEMU had the highest population of the older students who were above 50 years being 20 out of $55(8.2 \%)$ of the total population although some universities such as KU and UON had none of their students in that age bracket. The mean age of the students was $32.3 \pm 8.2(20.9-58.8)$. GLUK had the highest mean age of $36.8 \pm 7.0(23.2-57.5)$ years, while UON had the lowest mean of $27.0 \pm 2.9(20.9-46.7)$.

Out of the total 1292, 945 (73.1\%) who sat for the NCK examination during the period July 2012 to June 2015 were female while 347 (26.9\%) were males. Across all the universities, the proportion of females exceeded the that of males with UEAB leading with 249 out of 301 (82. \%) of the students being females and only $52 \quad(17.3 \%)$ males, while Kenyatta University had the least with 67 out of 109 (61.5\%) females and $42(38.5 \%)$ males. Table 1 below illustrates the demographic characteristics.

Table-1. Socio-demographic characteristics of BScN students (July 2010-June 2015)

\begin{tabular}{|c|c|c|c|c|c|c|c|c|c|}
\hline Variable & Categories & $\begin{array}{l}\text { UEAB } \\
(\%) \\
\end{array}$ & $\begin{array}{l}\text { GLUK } \\
(\%)\end{array}$ & $\begin{array}{l}\text { KEMU } \\
(\%) \\
\end{array}$ & $\begin{array}{l}\text { KU } \\
(\%) \\
\end{array}$ & $\begin{array}{l}\text { MMUST } \\
(\%) \\
\end{array}$ & $\begin{array}{l}\text { Moi } \\
(\%) \\
\end{array}$ & $\begin{array}{l}\text { UoN } \\
(\%) \\
\end{array}$ & $\begin{array}{l}\text { Total } \\
(\%) \\
\end{array}$ \\
\hline \multirow[t]{3}{*}{ Gender } & Male & $\begin{array}{l}52 \\
(17.3)\end{array}$ & $\begin{array}{l}40 \\
(25.8) \\
\end{array}$ & $\begin{array}{l}48 \\
(19.6)\end{array}$ & $\begin{array}{l}42 \\
(38.5) \\
\end{array}$ & $64 \quad(33.3)$ & $\begin{array}{l}32 \\
(30.5) \\
\end{array}$ & $\begin{array}{l}69 \\
(37.3) \\
\end{array}$ & $\begin{array}{l}347 \\
(26.9) \\
\end{array}$ \\
\hline & Female & $\begin{array}{l}249 \\
(82.7)\end{array}$ & $\begin{array}{l}115 \\
(74.2) \\
\end{array}$ & $\begin{array}{l}197 \\
(80.4) \\
\end{array}$ & $\begin{array}{l}67 \\
(61.5) \\
\end{array}$ & $128(66.7)$ & $\begin{array}{l}73 \\
(69.5) \\
\end{array}$ & $\begin{array}{l}116 \\
(62.7) \\
\end{array}$ & $\begin{array}{l}945 \\
(73.1) \\
\end{array}$ \\
\hline & Total & 301 & 155 & 245 & 109 & 192 & 105 & 185 & 1292 \\
\hline \multirow[t]{5}{*}{$\begin{array}{l}\text { Age group in } \\
\text { years }\end{array}$} & $20-29$ & $\begin{array}{l}128 \\
(42.5)\end{array}$ & $\begin{array}{l}17 \\
(11.0)\end{array}$ & $\begin{array}{l}74 \\
(30.2)\end{array}$ & $\begin{array}{l}94 \\
(86.3)\end{array}$ & $\begin{array}{l}92 \\
(47.9)\end{array}$ & $\begin{array}{l}89 \\
(84.8)\end{array}$ & $\begin{array}{l}173 \\
(93.5)\end{array}$ & $\begin{array}{l}667 \\
(51.6)\end{array}$ \\
\hline & $30-39$ & $\begin{array}{l}110 \\
(36.5)\end{array}$ & $\begin{array}{l}95 \\
(61.3)\end{array}$ & $\begin{array}{l}95 \\
(38.8)\end{array}$ & $\begin{array}{l}14 \\
(12.8)\end{array}$ & $54 \quad(28.2)$ & $\begin{array}{l}12 \\
(11.4)\end{array}$ & $\begin{array}{l}10 \\
(5.4)\end{array}$ & $\begin{array}{l}390 \\
(30.2)\end{array}$ \\
\hline & $40-49$ & $\begin{array}{l}50 \\
(16.6) \\
\end{array}$ & $\begin{array}{l}35 \\
(22.6) \\
\end{array}$ & $\begin{array}{l}56 \\
(22.9) \\
\end{array}$ & $\begin{array}{l}1 \\
(0.9) \\
\end{array}$ & $35 \quad(18.2)$ & $\begin{array}{l}1 \\
(1.0) \\
\end{array}$ & $\begin{array}{l}2 \\
(0.9)\end{array}$ & $\begin{array}{l}180 \\
(13.9) \\
\end{array}$ \\
\hline & $>=50$ & $\begin{array}{l}13 \\
(4.3) \\
\end{array}$ & $\begin{array}{l}8 \\
(5.2) \\
\end{array}$ & $\begin{array}{l}20 \\
(8.2) \\
\end{array}$ & $\begin{array}{l}0 \\
(0.0)\end{array}$ & $\begin{array}{l}11 \\
(5.7)\end{array}$ & $\begin{array}{l}3 \\
(2.9)\end{array}$ & $\begin{array}{l}\mathrm{O} \\
(0.0)\end{array}$ & $\begin{array}{l}55 \\
(4.3) \\
\end{array}$ \\
\hline & Total & 301 & 155 & 245 & 109 & 192 & 105 & 185 & 1292 \\
\hline $\begin{array}{l}\text { Mean age in } \\
\text { years }\end{array}$ & $\begin{array}{l}\text { MeantSD } \\
\text { (Range) }\end{array}$ & $\begin{array}{l}33.4 \pm 8 . \\
3 \\
(22.4 \quad- \\
57.9)\end{array}$ & $\begin{array}{l}36.8 \pm 7 . \\
0 \\
(23.2 \quad- \\
57.5)\end{array}$ & $\begin{array}{l}36.0 \pm 8.5 \\
(23.0 \quad- \\
57.4)\end{array}$ & $\begin{array}{l}27.0 \pm 3 . \\
6 \\
(21.3 \quad- \\
47.2)\end{array}$ & $\begin{array}{l}32.8 \pm 9.2 \\
(21.5 \\
58.8)\end{array}$ & $\begin{array}{l}27.4 \pm 5 . \\
6 \\
(21.8 \quad- \\
53.1)\end{array}$ & $\begin{array}{l}27.0 \pm 2.9 \\
(20.9 \quad- \\
46.7)\end{array}$ & $\begin{array}{l}32.3 \pm 8 . \\
2 \\
(20.9 \quad- \\
58.8)\end{array}$ \\
\hline
\end{tabular}




\subsection{Institutional Characteristics and Performance}

Generally, all the institutions had $84.1 \%$ pass. The highest percentage pass was from MMUST (87.0\%), followed by KEMU $(85.3 \%)$ and the least was UON with $77.8 \%$ pass. See table 4.5 below illustrating performance by institution.

\begin{tabular}{|c|c|c|c|c|c|c|c|c|c|c|c|c|c|c|c|c|}
\hline \multirow{2}{*}{$\begin{array}{l}\text { Categori } \\
\text { es }\end{array}$} & \multicolumn{2}{|c|}{ UEAB } & \multicolumn{2}{|c|}{ GLUK } & \multicolumn{2}{|l|}{ KEMU } & \multicolumn{2}{|l|}{ KU } & \multicolumn{2}{|c|}{ MMUST } & \multicolumn{2}{|l|}{ MOI } & \multicolumn{2}{|l|}{ UON } & \multicolumn{2}{|l|}{ Total } \\
\hline & $\begin{array}{l}\text { Pass } \\
(\%) \\
\end{array}$ & $\begin{array}{l}\text { Fail } \\
(\%)\end{array}$ & $\begin{array}{l}\text { Pass } \\
(\%)\end{array}$ & $\begin{array}{l}\text { Fail } \\
(\%) \\
\end{array}$ & 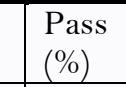 & $\begin{array}{l}\text { Fail } \\
(\%)\end{array}$ & \begin{tabular}{|l}
$\begin{array}{l}\text { Pass } \\
(\%)\end{array}$ \\
\end{tabular} & $\begin{array}{l}\text { Fail } \\
(\%)\end{array}$ & \begin{tabular}{l|l} 
Pass \\
$(\%)$
\end{tabular} & $\begin{array}{l}\text { Fail } \\
(\%)\end{array}$ & \begin{tabular}{|l}
$\begin{array}{l}\text { Pass } \\
(\%)\end{array}$ \\
\end{tabular} & $\begin{array}{l}\text { Fail } \\
(\%)\end{array}$ & \begin{tabular}{l|l} 
Pass \\
$(\%)$
\end{tabular} & $\begin{array}{l}\text { Fail } \\
(\%)\end{array}$ & \begin{tabular}{l|l} 
Pass \\
$(\%)$
\end{tabular} & $\begin{array}{l}\text { Fail } \\
(\%)\end{array}$ \\
\hline Total & $\begin{array}{l}251 \\
83.4\end{array}$ & $\begin{array}{l}50 \\
16.6\end{array}$ & $\begin{array}{l}130 \\
83.9\end{array}$ & $\begin{array}{l}25 \\
16.1\end{array}$ & $\begin{array}{l}209 \\
85.3\end{array}$ & $\begin{array}{l}36 \\
14.7\end{array}$ & $\begin{array}{l}98 \\
89.9\end{array}$ & $\begin{array}{l}11 \\
10.1\end{array}$ & $\begin{array}{l}167 \\
87.0\end{array}$ & $\begin{array}{l}25 \\
13.0\end{array}$ & $\begin{array}{l}88 \\
83.8\end{array}$ & $\begin{array}{l}17 \\
16.2\end{array}$ & $\begin{array}{l}144 \\
77.8\end{array}$ & $\begin{array}{l}41 \\
22.2\end{array}$ & $\begin{array}{l}1087 \\
84.1\end{array}$ & $\begin{array}{l}205 \\
15.9\end{array}$ \\
\hline
\end{tabular}

\subsection{Type of Institution and Performance}

Generally, the percentage pass was higher in the faith based institutions compared to the performance in the public institutions while being lowest in the private institutions. See fig 4.2 below

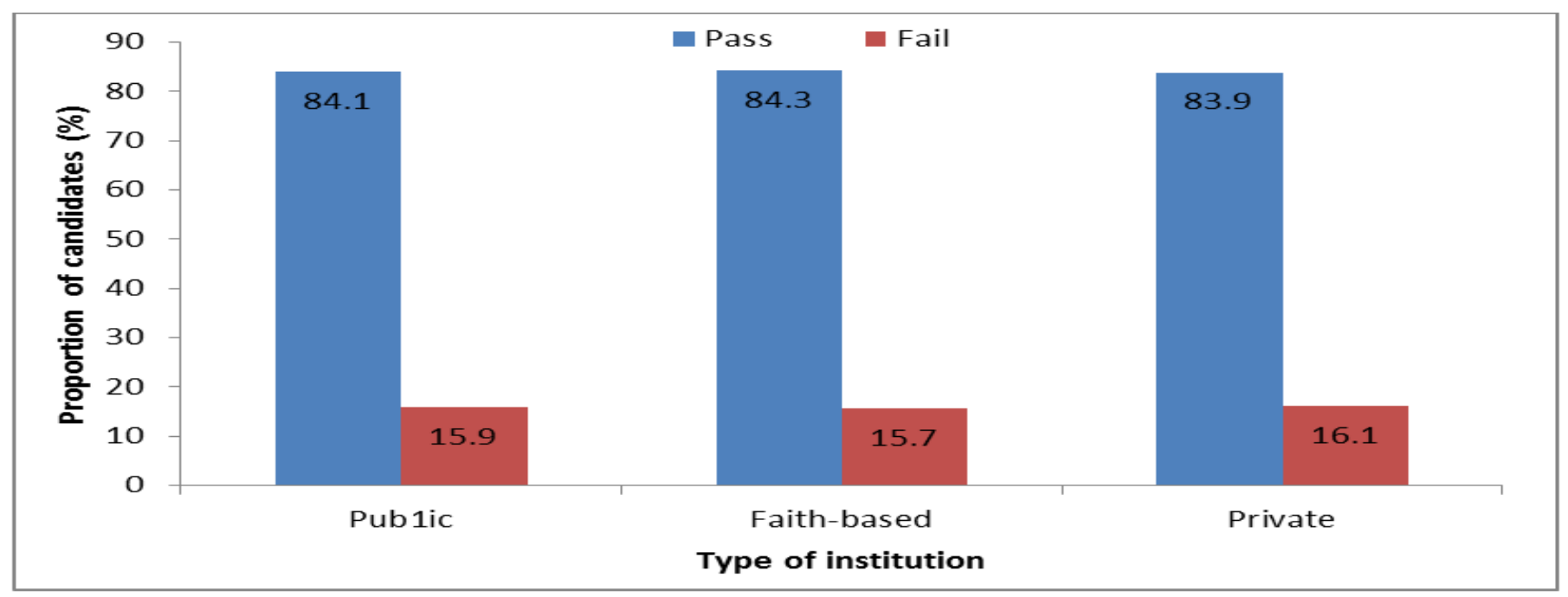

Source: From this study

Figure-2. Performance by type of institution (July 2012-June 2015)

Concerning the age, the highest percentage pass was registered among the ages 30-39 which was 349 out of $390(89.49 \%)$. In the same age group the Public institutions performed better than faith based institutions and private institutions respectively by having 84 out of $90(93.33 \%)$ against 184 out of $305(89.76 \%)$ and 81 out of 95 $(85.26 \%)$ respectively. Lowest performance was displayed among the ages $20-29$ across the institutions and was much lower in the private institutions being at 12 out of $17(70.59 \%)$ pass than public at 368 out of $448(82.14 \%)$ and faith based 161 out of $202(79.70 \%)$ and also comparing with ages above 50 that had higher percentages.

A total of $591(45.7 \%)$ belonged to public institutions, $546(42.3 \%)$ to faith based institutions while $155(12.0 \%)$ belonged to private. Overall, the proportion of males $(84.1 \%)$ and females $(84.1 \%)$ with a pass was comparable. By type of institution, females 98 out of $115(85.2 \%)$ in private institutions performed better than their male counterparts 32 out of $40(80 \%)$ in contrast to the public where the proportion of females with a pass was 320 out of $384(83.3 \%)$. The difference, was however, very slim in faith-based institutions where females with a pass constituted 377 out of $446(84.5 \%)$ and the males 83 out of 100 (83\%). See table 4.6 below.

Table-3. Performance by socio-demographic characteristics and type of institution (July 2012-June 2015)

\begin{tabular}{|c|c|c|c|c|c|c|c|c|}
\hline \multirow[t]{2}{*}{ Variable } & \multicolumn{2}{|l|}{ Public } & \multicolumn{2}{|c|}{ Faith-Based } & \multicolumn{2}{|l|}{ Private } & \multicolumn{2}{|l|}{ Total } \\
\hline & Pass (\%) & $\begin{array}{r}\text { Fail } \\
(\%) \\
\end{array}$ & $\begin{array}{l}\text { Pass } \\
(\%) \\
\end{array}$ & $\begin{array}{l}\text { Fail } \\
(\%)\end{array}$ & Pass (\%) & $\begin{array}{l}\text { Fail } \\
(\%)\end{array}$ & $\begin{array}{l}\text { Pass } \\
(\%) \\
\end{array}$ & $\begin{array}{l}\text { Fail } \\
(\%)\end{array}$ \\
\hline \multicolumn{9}{|l|}{ Gender } \\
\hline Male & $\begin{array}{l}177 \\
85.51 \\
\end{array}$ & $\begin{array}{l}30 \\
14.49 \\
\end{array}$ & $\begin{array}{l}83 \\
83.00 \\
\end{array}$ & $\begin{array}{l}17 \\
17.00 \\
\end{array}$ & $\begin{array}{l}32 \\
80.00 \\
\end{array}$ & $\begin{array}{l}8 \\
20.00 \\
\end{array}$ & $\begin{array}{l}292 \\
84.1 \\
\end{array}$ & $\begin{array}{l}55 \\
15.9 \\
\end{array}$ \\
\hline Female & $\begin{array}{l}320 \\
83.33\end{array}$ & $\begin{array}{l}64 \\
16.67\end{array}$ & $\begin{array}{l}377 \\
84.53\end{array}$ & $\begin{array}{l}69 \\
15.47\end{array}$ & $\begin{array}{l}98 \\
85.22\end{array}$ & $\begin{array}{l}17 \\
14.78\end{array}$ & $\begin{array}{l}795 \\
84.13\end{array}$ & $\begin{array}{l}150 \\
15.87\end{array}$ \\
\hline Total & $497(84.0)$ & $94(16.0)$ & $460(84.2)$ & $86(15.8)$ & $130(83.8)$ & $25(16.2)$ & $\begin{array}{l}1087 \\
(84.1)\end{array}$ & $205(15.9)$ \\
\hline \multicolumn{9}{|c|}{ Age groups in years } \\
\hline $20-29$ & $\begin{array}{l}368 \\
82.14 \\
\end{array}$ & $\begin{array}{l}80 \\
17.86 \\
\end{array}$ & $\begin{array}{l}161 \\
79.70 \\
\end{array}$ & $\begin{array}{l}41 \\
20.30 \\
\end{array}$ & $\begin{array}{l}12 \\
70.59 \\
\end{array}$ & $\begin{array}{l}5 \\
29.41 \\
\end{array}$ & $\begin{array}{l}541 \\
81.11 \\
\end{array}$ & $\begin{array}{l}126 \\
18.89 \\
\end{array}$ \\
\hline $30-39$ & $\begin{array}{l}84 \\
93.33 \\
\end{array}$ & $\begin{array}{l}6 \\
6.67 \\
\end{array}$ & $\begin{array}{l}184 \\
89.76 \\
\end{array}$ & $\begin{array}{l}21 \\
10.24 \\
\end{array}$ & $\begin{array}{l}81 \\
85.26 \\
\end{array}$ & $\begin{array}{l}14 \\
14.74 \\
\end{array}$ & $\begin{array}{l}349 \\
89.49 \\
\end{array}$ & $\begin{array}{l}41 \\
10.51 \\
\end{array}$ \\
\hline $40-49$ & $\begin{array}{l}32 \\
82.05 \\
\end{array}$ & $\begin{array}{l}7 \\
17.95 \\
\end{array}$ & $\begin{array}{l}89 \\
83.96 \\
\end{array}$ & $\begin{array}{l}17 \\
16.04 \\
\end{array}$ & $\begin{array}{l}31 \\
88.57 \\
\end{array}$ & $\begin{array}{l}4 \\
11.43 \\
\end{array}$ & $\begin{array}{l}152 \\
84.44 \\
\end{array}$ & $\begin{array}{l}28 \\
15.56 \\
\end{array}$ \\
\hline$>=50$ & $\begin{array}{l}13 \\
92.86\end{array}$ & $\begin{array}{l}1 \\
7.14\end{array}$ & $\begin{array}{l}26 \\
78.79\end{array}$ & $\begin{array}{l}7 \\
21.21\end{array}$ & $\begin{array}{l}6 \\
75.00\end{array}$ & $\begin{array}{l}2 \\
25.00\end{array}$ & $\begin{array}{l}45 \\
81.82\end{array}$ & $\begin{array}{l}10 \\
18.18\end{array}$ \\
\hline Total & 497 & 94 & 460 & 86 & 130 & 25 & 1087 & 205 \\
\hline
\end{tabular}

On subjecting the data to regression analysis, there was no association reported between the type of institution and performance. 
Table-4. Logistic regression analysis of institutional characteristics and Performance (July 2012-June 2015)

\begin{tabular}{|c|c|c|c|c|c|}
\hline Independent variable & $\begin{array}{l}\text { \% Pass } \\
(n=1087)\end{array}$ & $\begin{array}{l}\% \text { Fail } \\
(n=205)\end{array}$ & OR & $95 \% \mathrm{CI}$ & $P$ value \\
\hline \multicolumn{6}{|l|}{ Type of institution } \\
\hline Public & 84.1 & 15.9 & \multirow[t]{2}{*}{0.99} & \multirow[t]{2}{*}{$0.7-1.3$} & \multirow[t]{2}{*}{0.97} \\
\hline Others & 84.2 & 15.8 & & & \\
\hline Faith-based & 84.3 & 15.7 & \multirow[t]{2}{*}{1.0} & \multirow[t]{2}{*}{$0.8-1.4$} & \multirow[t]{2}{*}{0.92} \\
\hline Others & 84.1 & 15.9 & & & \\
\hline Private & 83.9 & 16.1 & \multirow[t]{2}{*}{0.9} & \multirow[t]{2}{*}{$0.6-1.5$} & \multirow[t]{2}{*}{0.92} \\
\hline Others & 84.2 & 15.8 & & & \\
\hline
\end{tabular}

Source: From this study

\subsection{Admission Criteria and Performance}

The selection criteria of all institutions conformed to the nursing council requirements for entry into BScN program which was a $\mathrm{C}+$, however different university admission cutoff points differed depending on individual university thus ranging from 40.1 to 46.8 points (raw cluster) and basic aggregate of 74 to 80 points As much as the cutoff point was clear for university entry, those students admitted on KUPPS programme were admitted with higher points compared to those admitted on the parallel programme commonly referred to as PSSP which accepted students to same program but with a minimum qualification of $\mathrm{C}+$ mean score with basic aggregate of 46 52 points. There is a clear 28 aggregate point difference in students admitted to the university in the two programs. At the same time each individual public university had its own cut off point for the nursing course thus bringing variation even among the public universities in terms of entry points.

Private and faith based institutions differed on their selection criteria although they were able to conform to the nursing council requirements for admission into the $\mathrm{BScN}$ program. Irrespective of all these the key informants reported that majority of the students who were direct entry and who enrolled on parallel programme performed poorly compared to their counterparts who were admitted through the KUPPS and this was reported by 2 out of 3 ( $66.7 \%$ ) of the total participants in the GoK institutions. However this information was only valid for the public universities because the private universities did not utilize the same criteria for admission.

\subsection{Mode of Study and Performance}

All the institutions under study had both the upgrading and direct entry group of students. All upgraders for the purpose of study were mature entry ages 30 and above. Basing on the age of the student therefore, there was a significant relationship between age and performance with those higher than 30 years performing better than those below 30 years. (OR: 1.6, 95\% CI: 1.2-2.2, p= 0.002). On the same understanding 4 out six (66.7\%) of the key informants reported that part-timer students performed better than the full time counterparts.

\subsection{School Policies and Performance}

School policies examined included teaching methods, class attendance and pass mark. The institutions chiefly reported to be either using problem based learning or mixed methods. All the institutions had policies on class attendance with some having it at $75 \%$ attendance and above while others were below $75 \%$. However the enforcement of the policies could not be elicited from the respondents. The policy on class attendance displayed marginal relationship with performance (OR: $0.4,95 \% \mathrm{CI}: 1.0-2.0, \mathrm{p}=0.068)$ thus indicating that the institutions with class attendance policy of $75 \%$ and above were likely to perform better than those with below $75 \%$ class attendance. While teacher absenteeism is not acceptable in all institutions, only private and faith based institutions had clear policies on handling the vice accounting to $3(50 \%)$ of the population of study. Comparing the performance using the above policies, there was no significant relationship that existed between the teaching methods adopted by the institutions and performance of the students in the nursing council examinations in the same institutions (OR:1.0, 95\% CI: 0.7-1.4, $\mathrm{p}=0.93$ ). The pass mark policy was also established not to be having insignificant relationship between those institutions having $50 \%$ pass mark and those of $40 \%$ pass mark and the performance in the NCK examinations. (OR: 1.0, 95\%CI: $0.6-1.5, \mathrm{p}=1.0$ ).

Table-5. Logistic regression analysis of institutional policies and Performance*

\begin{tabular}{|c|c|c|c|c|c|}
\hline Independent variable & \% Pass* $(n=989)$ & $\%$ Fail* $(n=194)$ & OR & $95 \% \mathrm{CI}$ & $P$ value \\
\hline \multicolumn{6}{|l|}{ Teaching methods } \\
\hline Problem -based & 83.5 & 16.5 & \multirow[t]{2}{*}{1.0} & \multirow[t]{2}{*}{$0.7-1.4$} & \multirow[t]{2}{*}{0.93} \\
\hline Mixed methods & 83.7 & 16.3 & & & \\
\hline \multicolumn{6}{|c|}{ Policy on class attendance } \\
\hline$=<75$ & 84.8 & 15.2 & \multirow[t]{2}{*}{0.4} & \multirow[t]{2}{*}{$1.0-2.0$} & \multirow[t]{2}{*}{0.068} \\
\hline$<75$ & 80.0 & 20.0 & & & \\
\hline \multicolumn{6}{|l|}{ Pass mark policy } \\
\hline $50 \%$ & 83.6 & 16.4 & \multirow[t]{2}{*}{1.0} & \multirow[t]{2}{*}{$0.6-1.5$} & \multirow[t]{2}{*}{1.0} \\
\hline $40 \%$ & 83.9 & 16.1 & & & \\
\hline
\end{tabular}

Source: From this study

\subsection{Teacher Characteristics and Performance}

The faculty student ratio for the schools of nursing was calculated basing on the total number of the students and faculty in the schools during the period of study. Basing on the key informant data collected illustrated in table 4.10 below, Three out of six institutions had their total student faculty ratio at 1:7 and one at 1:10 thus making it 4 out of $6(66.7 \%)$ that met the nursing council of Kenya requirement of the ratio of 1:10 or less. However one institution had a ratio of $1: 15$ which was almost twice the smallest ratio of 1:7. The institution that recorded the highest performance pass had the lowest ratio of 1:15 with total faculty while the least performance was recorded from an institution with a ratio of $1: 10$. 
A logistic regression analysis of the faculty student ratio and performance was done for both full-time and parttime faculty and fulltime faculty alone. The normal recommended nursing council of Kenya ratio of 1:10 was used to distinguish between the normal and abnormal ratio. The findings revealed no significant relationship between ratio of faculty to student and performance (OR: 0.9, 95\%CI 0.6-1.2: $\mathrm{p}=0.38$ ) and (OR: $1.0,95 \%$ CI: $0.7-1.5, p=1.0)$ respectively. The chances of passing or failing could therefore not be altered by an increase or decrease in the faculty student ratio in the schools of nursing.

Table-6. Ratio for fulltime and part-time faculty to student (July 2012-June 2015)

\begin{tabular}{l|l|l|l|l|l|l}
\hline & MOI & MMUST & UON & UEAB & KEMU & GLUK \\
\hline Faculty part-time/full-time & 26 & 28 & 36 & 33 & 38 & 27 \\
\hline Number of faculty full-time alone & 21 & 22 & 26 & 23 & 15 & 21 \\
\hline Number of students & 183 & 400 & 344 & 393 & 232 & 186 \\
\hline Ratio total faculty/students & $1: 7$ & $1: 15$ & $1: 10$ & $1: 12$ & $1: 7$ & $1: 7$ \\
\hline Ratio full-time faculty alone & $1: 9$ & $1: 19$ & $1: 14$ & $1: 17$ & $1: 16$ & $1: 9$ \\
\hline
\end{tabular}

Source: From this study

Table-7. Logistic regression analysis of faculty-student ratio and Performance*

\begin{tabular}{|c|c|c|c|c|c|}
\hline Independent variable & $\begin{array}{l}\text { \% Pass* } \\
(n=989)\end{array}$ & $\begin{array}{l}\% \text { Fail } * \\
(n=194)\end{array}$ & OR & $95 \% \mathrm{CI}$ & P value \\
\hline \multicolumn{6}{|c|}{ Ratio of faculty(full-time and part-time) to students } \\
\hline$=<1: 10$ (normal & 82.7 & 17.2 & \multirow[t]{2}{*}{0.9} & \multirow[t]{2}{*}{$0.6-1.2$} & \multirow[t]{2}{*}{0.38} \\
\hline$>1: 10$ & 84.8 & 15.2 & & & \\
\hline \multicolumn{6}{|c|}{ Ratio of faculty(full-time) to students } \\
\hline$=<1: 10$ (normal & 83.8 & 16.1 & \multirow[t]{2}{*}{1.0} & \multirow[t]{2}{*}{$0.7-1.5$} & \multirow[t]{2}{*}{1.0} \\
\hline$>1: 10$ & 84.5 & 16.5 & & & \\
\hline
\end{tabular}

From this study *One of the institutions that was used as a pilot for key informant interviews was excluded from the analysis

Faculty qualification concept was represented by doctorate in nursing or nursing related field and Master of Science in nursing, while the experience was presented by mean faculty experience in years. The results revealed insignificant relationship between academic preparation; doctorate and performance with an (OR: 1.1, 95\% CI: 0.81.6, $\mathrm{p}=0.49)$. The mean faculty experience portrayed a marginal relationship with performance (OR: $0.7,95 \% \mathrm{CI}$ : $0.5-1.0, \mathrm{p}=0.068)$.

Table-8. Logistic regression analysis of faculty academic qualification and experience and Performance*

\begin{tabular}{|c|c|c|c|c|c|}
\hline Independent variable & $\begin{array}{l}\text { \% Pass* } \\
(\mathrm{n}=989)\end{array}$ & $\begin{array}{l}\% \text { Fail } * \\
(n=194)\end{array}$ & OR & $95 \% \mathrm{CI}$ & P value \\
\hline \multicolumn{6}{|l|}{$\begin{array}{l}\text { Total number of faculty basing on academic qualification } \\
\text { (doctorate in nursing) }\end{array}$} \\
\hline$\geq 3$ & 84.9 & 15.1 & \multirow[t]{3}{*}{1.1} & \multirow[t]{3}{*}{$0.8-1.6$} & \multirow[t]{3}{*}{0.49} \\
\hline$<3$ & 83.1 & 16.9 & & & \\
\hline$<13$ & 84.8 & 15.2 & & & \\
\hline \multicolumn{6}{|l|}{ Mean years of experience of faculty years } \\
\hline$=<10$ & 80.0 & 20.0 & \multirow[b]{2}{*}{0.7} & \multirow[b]{2}{*}{$0.5-1.0$} & \multirow[b]{2}{*}{0.068} \\
\hline$>10$ & 84.8 & 15.2 & & & \\
\hline
\end{tabular}

Source: From this study

\section{Discussions}

The fact that there was no significant relationship between school type and passing is an indicator that there could be no difference basing on admission criteria because all the faith based and private institutions admission criteria was different from the GoK criteria except for the upgrading group. Similar findings also found no relationship between the high school grade which is used during the selection process and performance (Oducado and Penuela, 2014) with results being $(\mathrm{t}=0.441)$. However other studies identified strong relationship between entry qualifications and performance in the licensure examination which was statistically significant $(\mathrm{r}=0.48 ; \mathrm{P}<$ 0.05) (Ogbonnaya et al., 2014); (Kija et al., 2016) $(<\mathrm{P}=0.022)$ and Pitt et al. (2012) $(\mathrm{P}=0.001)$. Key informants in this study from the public schools also conveyed a feeling of existence of relationship between entry qualifications and performance by stating that those who entered the system through the PSSP program and direct entry mode performed poorer. On the other hand some studies showed relationship between types of school with passing the licensure examination where by the private school had been displayed to perform better than state schools (Idowu, 2013). Kija et al. (2016) and Sabitu et al. (2012) reported no influence of school type on performance (school $<\mathrm{P}=$ $0.059>$ ). As much as the percentage pass was higher in the faith based institutions compared to the performance in the public institutions while being lowest in the private institutions, the $\mathrm{p}$ values of type of school demonstrated no relationship with all the $p$ values ranging from 0.92-0.97.

There was a significant relationship between age and performance with those higher than 30 years who were part time upgraders performing better than those below 30 years who were mostly direct entry. (OR: 1.6, 95\% CI: 1.2-2.2, $\mathrm{p}=0.002)$. On the same understanding $4(66.7 \%)$ of the key informants reported that part timer students performed better than the full time counterparts. This results corroborate the findings of Sharchar (2010) that reported part time and distant leaners performing better although distant learning was eliminated from this study. There was no significant relationship that existed between the teaching methods adopted by the institutions and performance of the students in the nursing council examinations in the same institutions (OR: 1.0, 95\% CI: 0.7-1.4, $\mathrm{p}=0.93$ ). Those same findings are reflected in the pass mark policy with no significant relationship existing between those institutions having 50\% pass mark and those of 40\% pass mark (OR:1.0,95\% CI: 0.6-1.5, $\mathrm{p}=1.0$ ). However the policy on class attendance displayed marginal relationship with performance (OR: 0.4, 95\% CI: $1.0-$ 2.0, $\mathrm{p}=0.068$ ). This confirms the studies of Amitava et al. (2010); Alos et al. (2015); Jafta (2013) and (Arulampalam et 
al., 2012) who demonstrated that both teacher and student absenteeism resulted in reduction in academic performance

The findings revealed no significant relationship between ratio of faculty to student with $p$ values of normal being 0.38 and the abnormal 1.0. The chances of passing or failing could therefore not be altered by an increase or decrease in the faculty student ratio. This contradicts the studies of Idowu (2013) and (Appiagyei et al., 2014) who found positive relationship between teacher student ratio and performance with higher number of teachers increasing the chances of student passing the examination the same findings were recounted by (Hazelkorn et al., 2013).The results revealed insignificant relationship between academic preparation; doctorate in nursing and performance with an (OR: 1.1,95\% CI: 0.8-1.6, p=0.49). This conquers with the findings of Mareike et al. (2013) in their study that found no relationship between teacher qualifications and performance though (Saddler et al., 2012) established a positive relation between teacher qualifications and passing.

Comparatively, mean faculty experience also portrayed a marginal relationship with performance (OR: 0.7, 95\% CI: $0.5-1.0, p=0.068)$. This matches with Eyewole (n.d) in his study that found out that the higher the number of years of experience, the better the individual teacher performance with better student outcomes. Darling (2010); King (2010) and Alos et al. (2015) in their study also identified positive correlation between the teacher experience in years and the learners' academic achievements.

\section{Conclusions}

Age had a significant relationship with performance this was because majority of the students aged 30 years and above performed better than their younger counterparts.

Type of institution had no relationship on performance among nursing students. This could be because apart from the classroom the institutions had little or no influence on clinical sites and this formed part of the learning of the nursing student.

Admission criteria was reported by the informants to be influencing performance in that those admitted with lower points in the parallel program were felt to have lesser performance as compared to their counterparts admitted with higher grades. However the ones utilizing the part-time mode of study who were mainly upgraders performed better irrespective of their lower entry grade.

School policies such as class attendance had a significant relationship with performance with those institutions upholding class attendance policy at $75 \%$ and above performing better than those that had it at lower than $75 \%$. However the pass mark policy did not display any relationship with performance same to the policy on teaching methods.

Teacher characteristics were also examined to include faculty qualifications, student faculty ration and faculty experience. Only faculty experience revealed relationship with performance with those institutions having mean faculty experience 10 years and above performing better than those with experience below 10 years.

\section{Recommendations}

Nursing council should consider updating the data base to cover all variables captured from student and institutions of nursing. This includes marital status, employment status and agency, time of exit from nursing schools among others.

Schools of nursing to continue with upgrading Programmes.

Schools of nursing to uphold class attendance policy of $75 \%$ and above attendance.

Schools of nursing to consider faculty experience during the recruitment process

\section{References}

Alleyama, J., R. Lakhani, P. Cruz, J. Pandit, V. Deshpande and S. Bhagat, 2012. A study of selected factors influencing academic performance of first year basic nursing students of colleges affiliated to Maharastra univerisy of health sciences, Hashik. Virginia Hunderson Global Nursing e Repository.

Alos, B.S., C.L. Caranto and J.J. David, 2015. Factors affecting academic performance student nurses of BSN. International Journal of Nursing Science, 5(2): 60-65. View at Google Scholar

Amitava, R., D. Manoji, S. Saswata and M.G. Braja, 2010. Factors affecting student academic performance. Bangladesh e-Journal of Socialogy, 7(2): 34-41.

Appiagyei, A.A., N.R. Kiriinya, M.J. Gross, N.D. Wambua, O.E. Oywer and K.A. Kamenju, 2014. Appiagyei et al h informing the scale-up of Kenyas nursing workforce: A mixed methods study of factors affecting pre-service training capacity andproductionuman resouses for health, 12(47): 1-10.

Arulampalam, W., A.R. Naylor and J. Smith, 2012. Am I missing something: The effect of absence from class on student performance? Journal of Economics Education Review, 31(4): 363-375. View at Google Scholar $\mid$ View at Publisher

Bishop, J.L. and M.A. Verleger, 2013. Flipped classroom. American Society for Engineering Education Journal. 120th ASEE Annual Conference and Exposition Paper Presentation, Paper ID \#6219.

Burns, M.S., 2011. Predicting academic progresion for student registerd nurse anaesthetist. AANA Journal, 79(3): 193-201. View at Google Scholar

Carrick, J.A., 2011. Student achievement and NCLEX-RN success: Problems that persist. Nursing Education Perspectives, 32(2): 78-83. View at Google Scholar | View at Publisher

Coons, I., 2014. Use of standardised tests within nursing education programs. USA: Las Vegas.

Cooper, E.S., 2012. Examining student achievement and curricullum in a nursing program at a midwestern community college. Retrieved from http://lib.dr.iastate.edu/etd.

Darling, H., 2010. Evaluating Teacher Effectiveness: How Teacher Performance Assesements can Measure and Improve Teaching: Centre of American Progress Report.

Dubois, D., D. Marie, P. Pomey, Girard and I. Brault, 2013. Conceptualizing performance of nursing care as a prerequisite for better measurement: A systematic and interpretive review. BMC Nursing, 12(1): 7. View at Google Scholar $\mid$ View at Publisher

Eyewole, n.d. The influence of teaching experience on the job performance of secondary school teachers in Ekiti State Nigeria. International Journal of Research Development 102-109.

Freeman, S.E., M.M. Donough, K.M. Smith, N. Okoroafor, H. Jordt and M.P. Wenderoh, 2013. Active learning increases student performance in science, engineering and mathematics. National Academy for Science of the United States of America, 111(23): 8410-8415.

Hamid, S.R., S.S.S. Hassan and N.A. Ismael, 2012. Teaching quality and performance among experienced teachers in Malaysia. Australian Journal of Teacher Education, 37(11): 5. View at Google Scholar | View at Publisher 
Hazelkorn, E., P. Wells and M. M., 2013. World-class universities or world class systems? Rankings and higher education policy choices Rankings and accountability in higher education: Uses and misuses, UNESCO. Paris: Center for Social Education and Research Dubling Institute of Technology Journal. pp: 1-23.

Idowu, M.E., 2013. Relationship between school quality and students performance in selected schools of nursing in South Western Nigeria IOSR Journal of Nursing and Health Science, 3(1): 37-46.

Jafta, M.G., 2013. Perception of tutors and student nurses on factors that influence academic performance at a nursing college.

Kenya Nursing Workforce Report, 2012. The status of nursing in Kenya. Nairobi: PEPFAR.

Kija, M., E. Nyangena and W. Kijinji, 2016. A comparative analysis of academic performance of diploma nursing student of public, private and faith based schools in Tanzania. International Jounal of Nursing Education, 8(2): 151-157. View at Google Scholar $\mid$ View at Publisher

King, J.R., 2010. The impact of teacher experience: Examining the evidence and policy implications. National Centre For Analysis of Longitudinal Data In Education Research. Brief No. 11.

Manieri, E., D.M. Lima and N. Ghosal, 2015. Testing for success; a logistic regresion analysis todetrmine which pre admission exam best predicts success in an associate degree nursing program. Journal of the National Organization for Associate Degree Nursing, 10(1): 25-29. View at Google Scholar | View at Publisher

Mareike, K., K. Utta, B. Jurgen, R. Dirk, V. Thamar and H. Avinja, 2013. Professional competence of teachers: Effects on instruction quality and students. Journal of Educational Psychology, 105(3): 805-820. View at Google Scholar $\mid$ View at Publisher

Missildine, K., R. Fountain, L. Summers and K. Gosselin, 2013. Flipping the classroom to improve student performance. Journal of Nursing Education. View at Google Scholar

NCK, 2015. NCK 2015 January results for BScN. Nairobi.

Nyangena, E., A. Getanda and S. Ngugi, 2013. Factors influencing success in bachelor of science in nursing graduates in nursing council of Kenya licensure examination. Baraton Interdisciplinary Research Jounal, 3(1): 11-21.

Oducado, M.R. and C. Penuela, 2014. Predictors of academic performance in profesional nursing school in a private school in Kalibo, Aklan, phillipines. Asia Pacific Journal of Education and Science, 1(5): 21-28.

Ogbonnaya, P.N., O.U. Okpuruka, I. Perpetua, N.P. Heanacho and I. Ndu, 2014. Academic performance in basic schools of nursing in Enugu State between 1995 and 1999. Scirp.org/Journal/ce. Retrieved from http://dx.doi.org/10.4236/ce.2014.510084.

Oh, K., H.Y. Ahn, H. Lee, I. Kim and K. Choi, 2011. Study on Korean nursing students educational outcomes. Journal of Educational Evaluation for Health Profesions, 8(3): 1-8. View at Google Scholar

Pitt, V., D. Powis, T. Levelt-Jole and S. Hunter, 2012. Factors influencing nursing student academic and clinical performance and attrition: An integrated literature review. Nurse Education Today, 32(8): 903-913. View at Google Scholar | View at Publisher

RENRE, 2014. A preparation guide: Regional examination for nurse regulation CARICOM countries. Kingston, Jamaica, USA: The Garrison, St Michael BB14038.

Sabitu, A.O., E.G. Babatunde and A.F. Oluwole, 2012. School types, facilities and academic performance of students in senior secondary schools in Ondo State Nigeria. International Educational Studies, 5(3): 44-48. View at Google Scholar $\mid$ View at Publisher

Saddler, M.P., G. Sonnert, P.H. Coyle, N. Cook-Smith and J.L. Miller, 2012. Influence of teacher knowledge on student learning in the middle school of physical science classrooms. American Educational Research Journal, 50(5): 1020-1049.

Sharchar, M., 2010. 20 years of research onacademic perfomance differences between traditional and distance learning summative meta analysis and trend exaamination. MERLOT Jounal of Online Learning and Teaching, 6(2): 318-334.

Ukpong, D.E. and I.N. George, 2013. Length of study-time behavior and academic achievement of social studies education students in the University of Uyo. International Education Studies, 6(3): 172-178. View at Google Scholar | View at Publisher

Xiao, H., W. Weiwei, Y. Lin and X. Zhang, 2014. Relationship of academic courses and clinical internship to performance of national qualifying examination for the register of profesional nurses. International Journal of Nursing, 1(4): 400-404. View at Google Scholar View at Publisher 